\title{
Physical Properties and Exchange System of Seawater in Royal Yacht Club Marina in the Northernmost Gulf of Aqaba
}

\author{
Riyad Manasrah ${ }^{1,2}$, Thekrayat Al-Majali ${ }^{1}$ \\ ${ }^{1}$ Faculty of Marine Sciences, The University of Jordan, Aqaba, Jordan; ${ }^{2}$ Mote Marine Laboratory, Sarasota, FL, USA \\ Correspondence to: Riyad Manasrah, r.manasrah@ju.edu.jo \\ Keywords: Temperature, Salinity, Total Hydrocarbon, Flushing Time, Marina, Royal Yacht Club, Gulf of Aqaba \\ Received: March 21, 2019 \\ Accepted: April 16, 2019 \\ Published: April 19, 2019 \\ Copyright () 2019 by authors and Scientific Research Publishing Inc. \\ This work is licensed under the Creative Commons Attribution International License (CC BY 4.0). \\ http://creativecommons.org/licenses/by/4.0/

\section{(c) (i) Open Access}

\section{ABSTRACT}

This research was aimed at studying the general environmental status of the marina at Royal Yacht Club (RYC), which is located in the Jordanian Gulf of Aqaba. The physical properties (temperature, salinity and density) were measured at surface and bottom water at 19 sites (T1 - T19). Total hydrocarbon was measured at surface at 12 sites (HC1-HC12). The water exchange and residence time were calculated using data of current speed and direction at 16 sites $(\mathrm{C} 1-\mathrm{C} 16)$. The mean values of temperature, salinity and density at surface and bottom waters in the RYC's marina were $27.13^{\circ} \mathrm{C} \pm 0.03^{\circ} \mathrm{C}, 40.51 \pm 0.02 \mathrm{psu}$ and $26.83 \pm 0.02$ $\mathrm{kg} \cdot \mathrm{m}^{-3}$, respectively. The results of physical parameters revealed no significant differences among sites, which are all comparable with open waters. The measurements range of total hydrocarbon in the marina was $1.404 \mathrm{mg} / 1$ (at site HC11) to $98.56 \mathrm{mg} / 1$ (at HC9). In general, all the high values of total hydrocarbon were found at the corners of the marina and at areas with relatively intense boats' movements. There was no correlation between distribution of total hydrocarbon and temperature $\left(\mathrm{R}^{2}=0.048 ; p=0.49\right)$ in the marina. Therefore, the major factors that influence the distribution of total hydrocarbon within the marina are the current system and boats' movements as well as the location reference to the gate. The residence time of waters inside the marina was 1.32 days. This flushing time is acceptable to secure good environmental conditions inside the marine to avoid stagnant seawater. The mean value of current speed at the RYC's marina gate with open water was $5.33 \pm 2.63 \mathrm{~cm} / \mathrm{s}$, which is relatively comparable with current speed in vicinity of study area. In conclusions, the environmental condition of the RYC's marina is acceptable in term of the residence time and exchange system with open water. Slightly high values of total hydrocarbon were detected, which can be solved by regular cleaning. 


\section{INTRODUCTION}

The Gulf of Aqaba is the north-eastern extension of the Red Sea. The water of the Gulf of Aqaba is the warmest among the world's seas due to the climate of the region. The Gulf of Aqaba is located in the sub-tropical arid zone between $28^{\circ}-29^{\circ} 30 \mathrm{~N}$ and $34^{\circ} 30-35^{\circ} \mathrm{E}$. It is a semi-enclosed basin that extends over a length of $180 \mathrm{~km}$ with a width between 5 and $25 \mathrm{~km}$ with an average of $16 \mathrm{~km}$ [1-3] (Figure 1).

The deepest point in the Gulf reaches $1825 \mathrm{~m}$ with an average depth of $800 \mathrm{~m}$. The bathymetry of the Gulf is arranged in three deep elongated basins separated from each other by relatively low sills. The Gulf is connected to the Red Sea by the Strait of Tiran, which has a sill depth of about $265 \mathrm{~m}$ [1-3].

The Gulf exhibits a seasonal cycle of stratification in spring, maintenance of a shallow thermocline in summer, and subsequent deepening of the thermocline to produce deep mixed layers in winter. Much of the seasonal stratification variability is determined by exchanges with the rest of the Red Sea. Nonetheless, inter-annual variability in wintertime temperatures appears to set the depth of maximum mixing. Because of being generally warm $\left(\mathrm{T}>21^{\circ} \mathrm{C}\right)$, and subject to dry winds much of the year, the Gulf is a site of high evaporation rates, estimated at $0.5-1.0 \mathrm{~cm} /$ day $[1,2,4,5]$.

Since the Gulf is a semi-enclosed concentration basin, the combined effects of exchange flow through the strait and evaporation produce a characteristic salinity profile with a noticeable subsurface salinity minimum in summer. The high salinity levels are very close to the physiological limits of many species, which highlights the potential sensitivity of its biota to any localized anthropogenic increases $[1,4]$.

Surface water temperature may approach $28^{\circ} \mathrm{C}$ during summer months and fall to just above $20^{\circ} \mathrm{C}$ in winter. Temperatures within the water mass reflect a degree of stratification versus vertical and lateral mixing by water currents. Vertically, temperature falls with depth in summer although there appears to be an inversion at certain depths in winter months because the deep water mass has a temperature reportedly above $20^{\circ} \mathrm{C}[1,4,6]$.
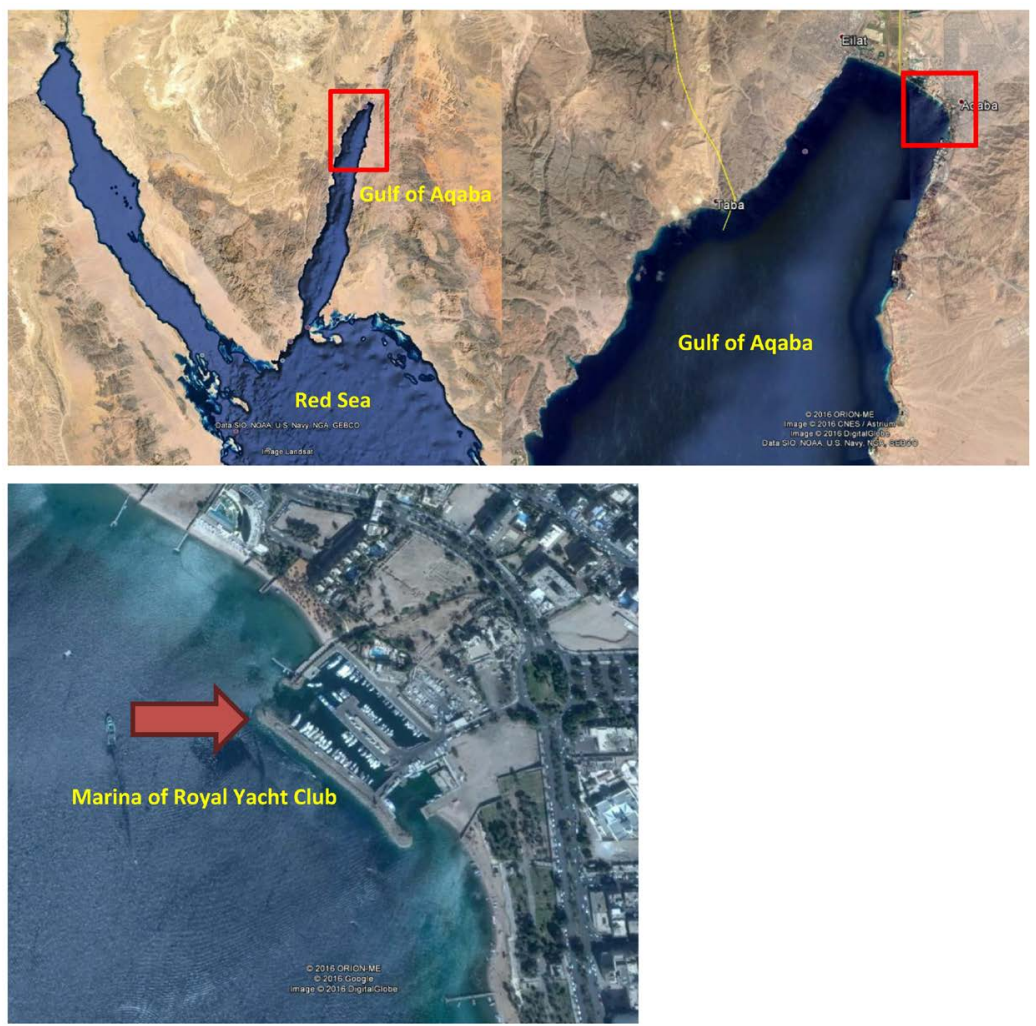

Figure 1. Map of study area at the Royal Yacht Club (RYC) marina in the northern Jordanian coast of Gulf of Aqaba (source: Google Earth). 
The annual meteorological measurements demonstrate that the wind speed fluctuates within a range of $0-12 \mathrm{~m} \cdot \mathrm{s}^{-1}$. Occasionally, wind speed reaches more than $15 \mathrm{~m} \cdot \mathrm{s}^{-1}$ but just for few hours. Moreover, a harmonic change of wind speed appears during summer causing a diurnal cycle that is represented by strong winds during daytime and relatively weaker winds during night-time. Meanwhile, northerly winds (NNW-NNE) dominate in the Gulf and represent about 85\%of total measurements [1].

A typical daily cycle of air temperature variations occurs during the whole year. Mean air temperature values range between $32.2^{\circ} \mathrm{C} \pm 3.16^{\circ} \mathrm{C}$ in summer and $17.6^{\circ} \mathrm{C} \pm 3.46^{\circ} \mathrm{C}$ in winter. In general, winds and air temperature have obvious effect on humidity; therefore, relative humidity shows periodic variation following the daily cycle of air temperature and wind speed. Minimum humidity recorded in summer is $13 \%$ compared to a maximum of $83 \%$ in winter [1].

Hydrocarbon is an organic compound consisting entirely of hydrogen and carbon and thus is group 14 hydride [7]. The majority of hydrocarbons found on earth naturally occur in crude oil, where decomposed organic matter provides an abundance of carbon and hydrogen $[8,9]$.

Oil pollution cause difficult changes of structure (causes complex changes in the structure) and function of natural ecosystems, as well as violation of metabolic processes, production and destruction of organic matter, and consequently leads to a decrease in species diversity. Studies show that planktonic animals are quite sensitive to oil pollution of seawater, which accelerates their death in the concentration of $0.01 \mathrm{mg} \cdot \mathrm{dm}^{-3}[10]$.

The coastal current pattern in the northern Gulf of Aqaba below $12 \mathrm{~m}$ depth is in general weak (3 - 6 $\mathrm{cm} \cdot \mathrm{s}^{-1}$ ) and fluctuated from east-northeastward to west-southwestward (parallel to the shoreline), which may be related to the effect of bottom topography and/or current density due to differential cooling between eastern and western parts in the study area, and wind-induced upwelling and downwelling in the eastern and western side, respectively. The prevailing northerly winds and stratification conditions during summer were the main causes of the southward current. [6]. Other previous studies [11-13] reported that wind events in the northern Gulf of Aqaba drive upwelling in the eastern side and downwelling in the western side; therefore westward current dominates there. Besides, [14] concluded that differential cooling of near- and offshore surface water during cold winter nights results in cross-shore gradient of density $\left(\sigma_{\mathrm{t}}\right)$ triggering gravity (density) currents. During summer, the prevailing northern winds and stratification conditions governed significantly the currents at upper $12 \mathrm{~m}$ depth, which are mostly directed to the south. Several studies showed that winds are effective external forces that govern surface and subsurface currents [11, 12, 15-17]. On the other hand, a vertical anticlockwise rotation in current direction from top to bottom was observed specifically during summer and autumn seasons, which may be related to the Ekman wind drift in the coastal region with vertical wall $[18,19]$, which predicts that a steady wind stress acting together with the Coriolis force will produce a transport of water to the right of the wind.

Marina is a dock or basin with moorings and supplies for yachts and small boats. A marina differs from a port in that a marina does not handle large passenger ships or cargo from freighters. Marinas may be located along the banks of rivers connecting to lakes or seas and may be inland. They are also located on coastal harbors (natural or man-made) or coastal lagoons, either as standalone facilities or within a port complex [20].

The marina at Royal Yacht Club (RYC) is the oldest marina at the Jordanian Gulf of Aqaba and it includes different anthropogenic activities that may influence the quality of seawater inside and outside the marina. In this research, this marina was selected in order to study the environmental status through investigating physical properties (temperature, salinity and density), total hydrocarbon as well as water exchange system and residence time in order to assess the environmental condition of the marina and any possible impacts in open sea.

\section{METHODOLOGY}

\subsection{Study Site}

The RYC's marina is located in northern part of Jordanian coast of the Gulf of Aqaba (Figure 1). The 
surface and volume of the marina are $19,154 \mathrm{~m}^{2}$ and $86,193 \mathrm{~m}^{3}$ respectively. The gate width is about $46.5 \mathrm{~m}$ and average depth is about $4.5 \mathrm{~m}$, the area of a vertical section at the gate is about $180 \mathrm{~m}^{2}$.

\subsection{Measurements of Seawater Temperature, Salinity and Density}

Physical properties (temperature, salinity and density) of seawater were measured using Conductivity, Temperature and Depth meter (CTD 19 plus V2) at all sites (T1 - T19). The initial accuracy and resolution for the CTD sensors are $\pm 0.0005,0.00007$ for conductivity; $\pm 0.005,0.0001$ for temperature; $\pm 0.1 \%, 0.002 \%$ for pressure, respectively.

The setup of the CTD device was prepared in the lab and then the CTD was casted in situ for measuring the seawater temperature, salinity, density at all sites (Figure 2).

\subsection{Total Hydrocarbon Measurements}

Twelve samples were collected inside the RYC's marina (Figure 3) in one liter brown bottles, which were pre-washed by hexan. A $25 \mathrm{ml}$ of $\mathrm{n}$-hexan was added in situ to each sample. In the laboratory, the samples were transferred to one liter separated funnel in order to extract hydrocarbon from seawater. After extraction, the extract was measured using spectrofluorometer (model SFM 25, BIO-TEK, Ex $310 \mathrm{~nm}$ Em $360 \mathrm{~nm})$.

\subsection{Current Measurements}

Water current measurements were recorded using a moored Acoustic Doppler Current Profiler (ADCP) Workhorse $300 \mathrm{kHz}$ (RD Instrument) sites (Figure 4). The records represent 30 seconds interval in 4 layers (depth cells) of the water column in the RYC's marina $(1-4 \mathrm{~m})$. The ADCP was designed to measure the horizontal and vertical current components at different layers in the water column which depend on the transmitting frequency.

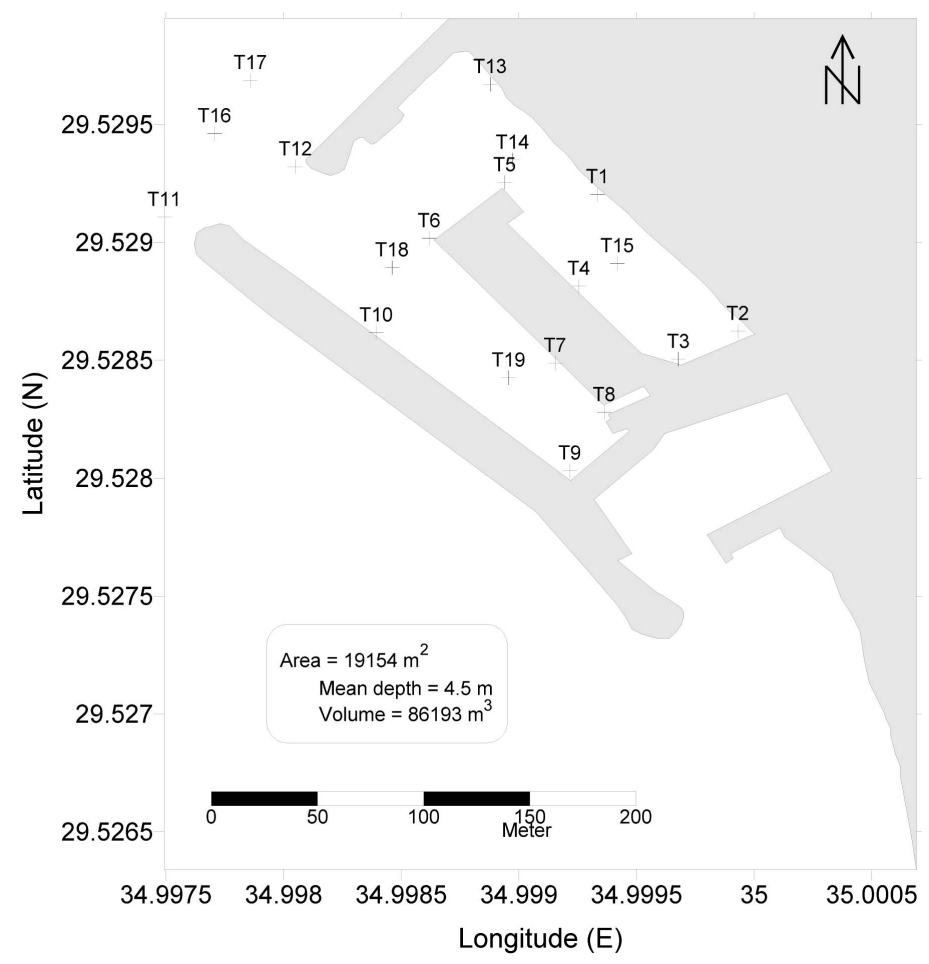

Figure 2. Map showing sites for measurement of seawater temperature, salinity and density at RYC's Marina. 


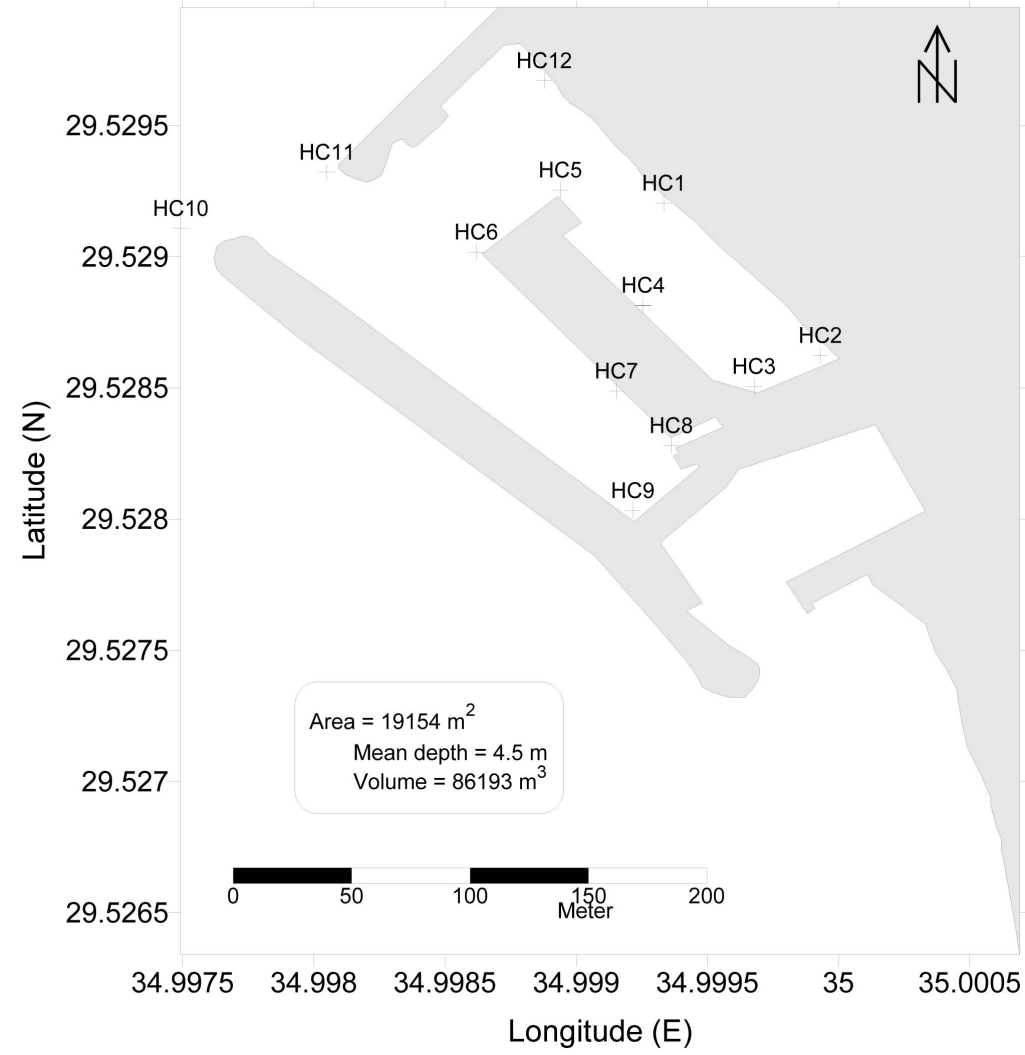

Figure 3. Map showing sites for measurement of total hydrocarbon at RYC's Marina.

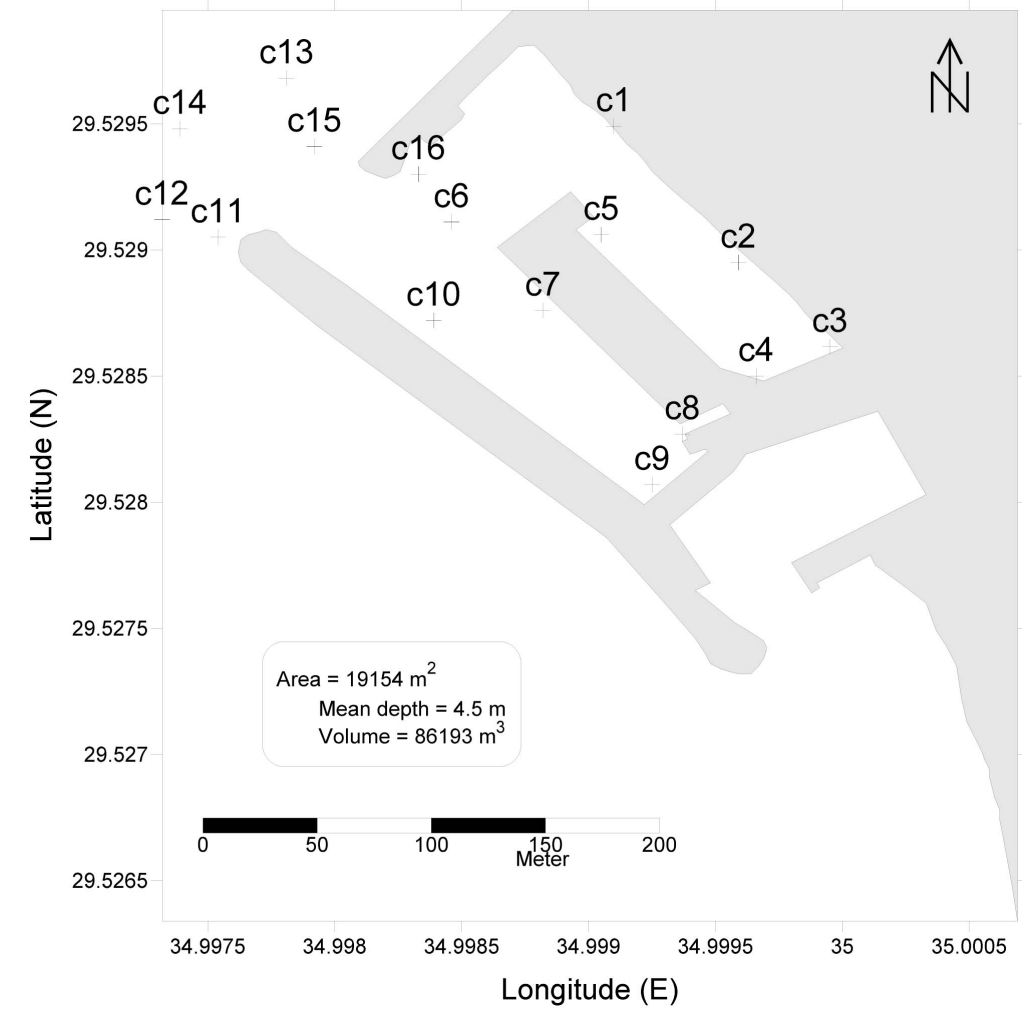

Figure 4. Map showing sites for measurement of currents at RYC's Marina. 


\subsection{Data Analysis Software}

Data analysis was performed using SPSS (SPSS v.20) for statistical tests and comparisons. The Surfer software was used for drawing contours figures of all variables. Besides, Excel software was used for sorting and filtering data and drawings.

\subsection{Residence Time Calculation}

The minimum flushing time ( $T_{\text {flushing }}$ ) of seawater inside the RYC's marina was calculated based on the equation (Figure 5):

$$
T_{\text {flushing }}=\frac{V o l}{V_{i}}
$$

where:

Vol is the total water volume $\left(\mathrm{m}^{3}\right)$ of seawater of RYC's marina.

$V_{i}$ is the inflow water $\left(\mathrm{m}^{3} / \mathrm{s}\right)$ through the gate at the marina, where $V_{i}$ can be calculated using the following relations:

$$
V_{i}=A \times \bar{v}
$$

where

$A$ is area of the vertical section at the gate $=w \times h$,

$W$ is the width of the vertical cross section at the gate,

$h$ is the mean depth of the vertical section at the gate, and

$\bar{v}$ is the average of current speed that perpendicular through the cross section of the gate.

\section{RESULTS AND DISCUSSIONS}

\subsection{Seawater Temperature}

Temperature measurements in the RYC's marina revealed weak variation among sites (Figure 6) in both bottom and surface, which ranges between $27.98^{\circ} \mathrm{C}$ and $26.51^{\circ} \mathrm{C}$ with mean value of $27.13^{\circ} \mathrm{C} \pm$ $0.03^{\circ} \mathrm{C}$. The temperature values on the surface were high and close to the maximum value $\left(27.98^{\circ} \mathrm{C}\right)$, where the increase of temperature values was at the corners of the lagoon. The temperature value at the bottom had more variations compared to at the surface. But at the gate, the temperature decreased and approach to the minimum recorded values $\left(26.51^{\circ} \mathrm{C}\right)$.

The results of temperature values in the marina are comparable with other studies in the Gulf of Aqaba. The temperature in the upper $300 \mathrm{~m}$ in the northern Gulf was high in summer $\left(\sim 26^{\circ} \mathrm{C}\right)$ and low in winter $\left(\sim 21^{\circ} \mathrm{C}\right)$ at the surface [21]. Another study shows the maximum temperature during mid-summer with maximum value in September $\left(26.99^{\circ} \mathrm{C}\right)$, while a minimum value was in March $\left(20.11^{\circ} \mathrm{C}\right)$ [4]. Reference [22] found the maximum temperature value in summer in Ayala lagoon was $27.76^{\circ} \mathrm{C}$. Besides, another study [23] showed that temperature records inside both marinas (Tala bay and Royal Yach Club) exhibited a gradual increase from April to September, reaching up to $27.5^{\circ} \mathrm{C}$, and then a decrease, attaining a minimum in February, March, or April, with the minima in different years varying in response to mixing depths. The lowest values recorded were near $21.0^{\circ} \mathrm{C}$ for all stations and were observed when mixing conditions predominated and the depth of the thermocline increased [23].

W

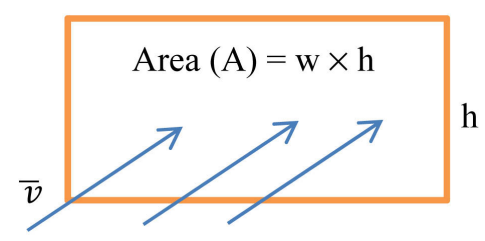

Figure 5. Diagram sketch of vertical cross section at the gate of RYC's marina. 

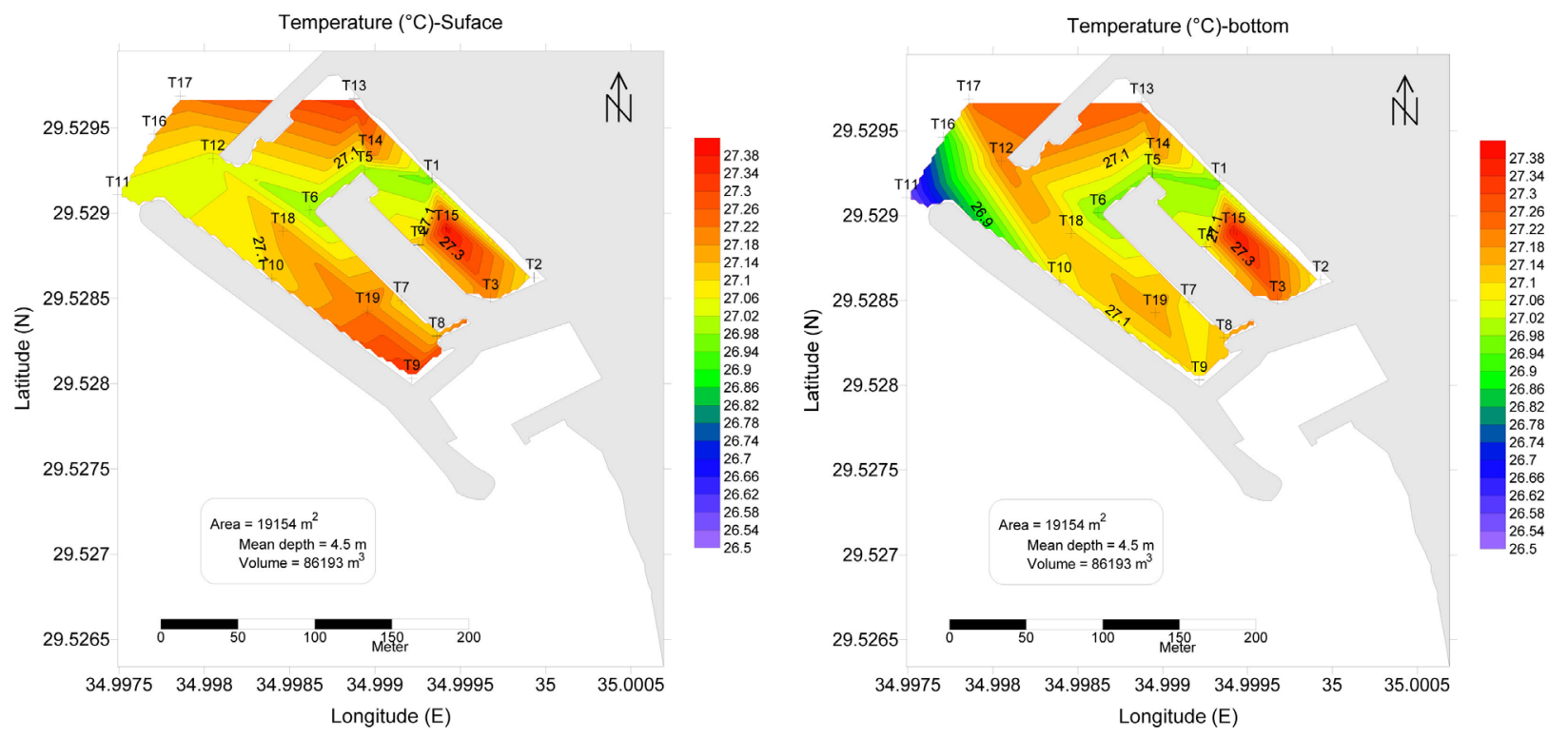

Figure 6. Temperature distribution of seawater $\left({ }^{\circ} \mathrm{C}\right)$ during summer at the sites (T1 - T19) in RYC's marina.

\subsection{Salinity}

Salinity measurements in RYC's marina revealed a weak variation among sites (Figure 7) in both surface and bottom, which was ranged between 40.38 - 40.76 psu with mean value of $40.51 \pm 0.02 \mathrm{psu}$. Salinity values on surface were lower than bottom, particularly near the gate. The range of surface salinity was $40.56-40.38$ psu. On the other hand, salinity at the bottom was close to the surface, but the disparity is clear at the gate of the lagoon.

In general, salinity values in the marina in this study are comparable with values in the Gulf of Aqaba. Reference [24] suggested that most of annual difference of salinity in the northern Gulf of Aqaba is due to the high evaporation and lower saline water inflow from the Red Sea. The salinity values of this study are comparable with previous studies, e.g. 40.33 - 40.78 [25], 40.3 - 40.7 [24, 26], 40.57 - 40.6 [27]. Besides, a study in Ayla lagoons [22] found the range of mean values of salinity in summer was $40.54-40.93$ psu.

Another study [23] found that salinity in both Tala Bay and Royal Yacht Club marinas fluctuated around 40.5 with very minor temporal and spatial variations.

\subsection{Density}

The relationship between density $\left(\mathrm{kgm}^{-3}\right)$ and temperature at all measurement locations (1 - 19) was inverse relationship (Figure 8 and Figure 11). The mean value of density for all sites at surface and bottom waters was $26.83 \pm 0.02 \mathrm{~kg} \cdot \mathrm{m}^{-3}$, the maximum was $27.57 \mathrm{~kg} \cdot \mathrm{m}^{-3}$, and the minimum value was 26.54 $\mathrm{kg} \cdot \mathrm{m}^{-3}$.

In general, density values in the RYC's marina in this study are comparable with values in the Gulf of Aqaba. A previous study [4] found that sigma-t at surface water in the northern Gulf of Aqaba ranged between $27.2-28.6 \mathrm{~kg} \cdot \mathrm{m}^{-3}$, while [28] reported a range of $26.87-28.51 \mathrm{~kg} \cdot \mathrm{m}^{-3}$. Besides, another study [6] observed maximum and minimum sigma-t between $27.62-28.88 \mathrm{~kg} \cdot \mathrm{m}^{-3}$. Reference [22] found the range of seawater density was $27.03 \mathrm{~kg} \cdot \mathrm{m}^{-3}$ in summer and $30.42 \mathrm{~kg} \cdot \mathrm{m}^{-3}$ in winter.

\subsection{Total Hydrocarbon}

The analysis of total hydrocarbon samples revealed that the lowest value was $1.404 \mathrm{mg} / \mathrm{l}$ at site $\mathrm{HC} 11$, and the maximum was $98.56 \mathrm{mg} / \mathrm{l}$ at $\mathrm{HC}$ (Figure 9). As was mentioned earlier, the surge in oil 

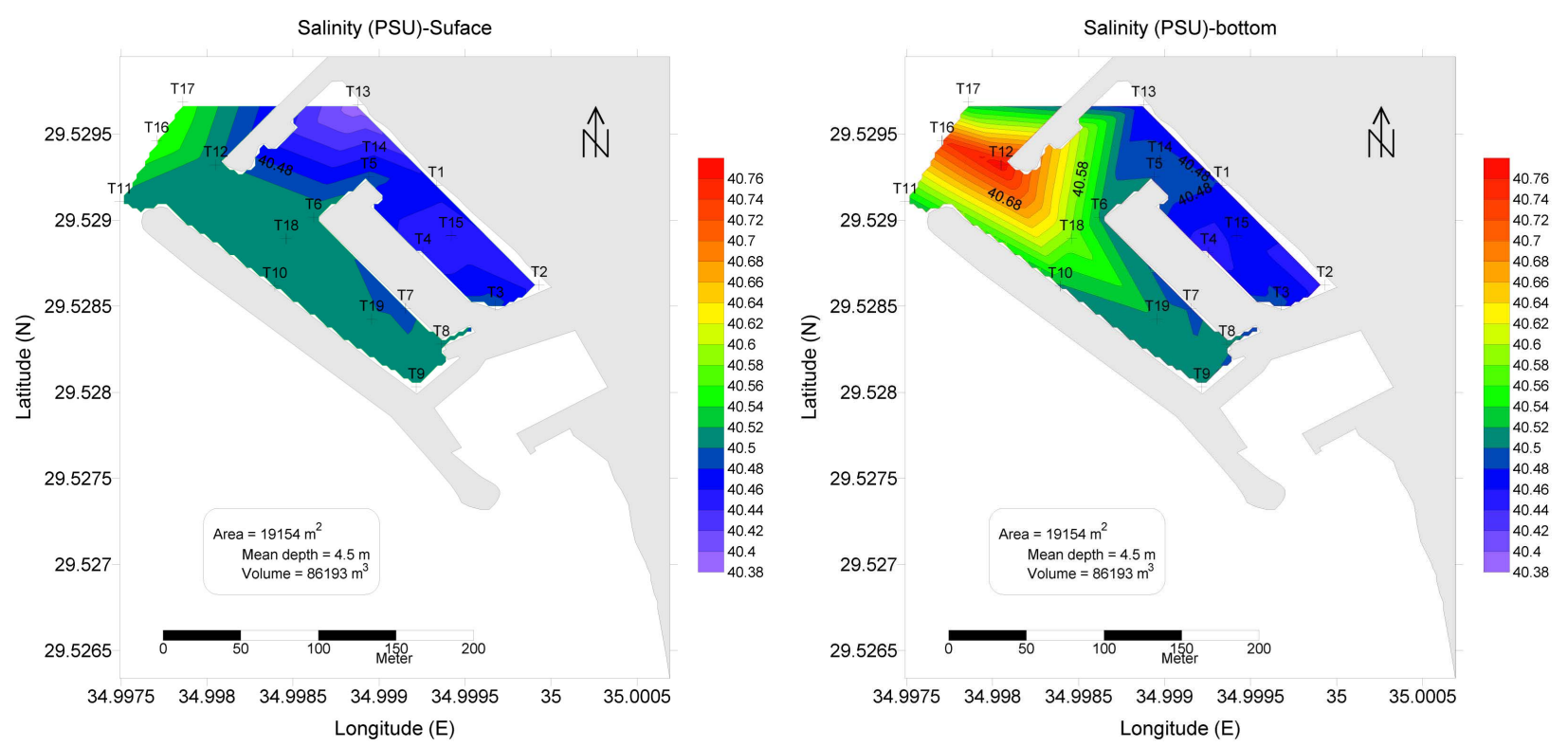

Figure 7. Salinity distribution (psu) of seawater during summer at the sites (T1 - T19) in RYC's marina.
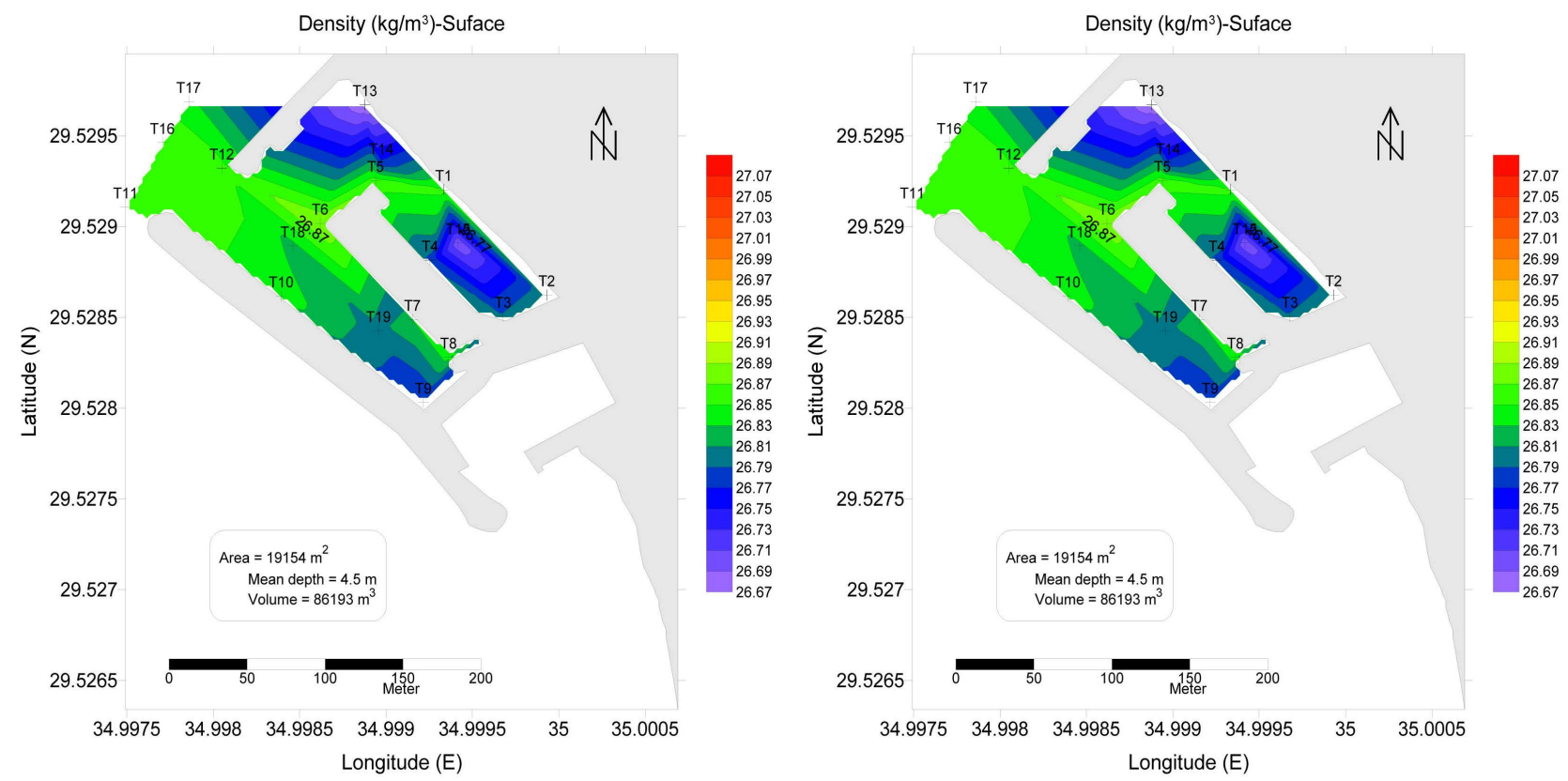

Figure 8. Density distribution $\left(\mathrm{kgm}^{-3}\right)$ of seawater during summer at the sites (T1 - T19) in RYC's marina.

concentrations may be due to the increasing numbers of boats or the site itself that is taking a sample of sea water is in a corner or near the corners. The highest concentrations were found at three locations (HC4 $=65.47 \mathrm{mg} / \mathrm{l} ; \mathrm{HC} 5=66.39 \mathrm{mg} / \mathrm{l} ; \mathrm{HC} 9=96.56 \mathrm{mg} / \mathrm{l})$. In general, the highest concentrations of total hydrocarbon were measured at locations either near corners (HC9) of the RYC's marina or at the place of cleaning and active anchoring of small ferry vessels (HC4 and HC5).

A justification of the high values at these sites that most of the total Hydrocarbon was gathering in the corners of the RYC. Increasing concentrations of oils usually is due to the intense movement of boats.

There is no published work on total hydrocarbon in the Gulf of Aqaba. A study in Sharm El-Maya bay investigated the Total Petroleum Hydrocarbons in seawater. In the surface water of the bay, TPH 


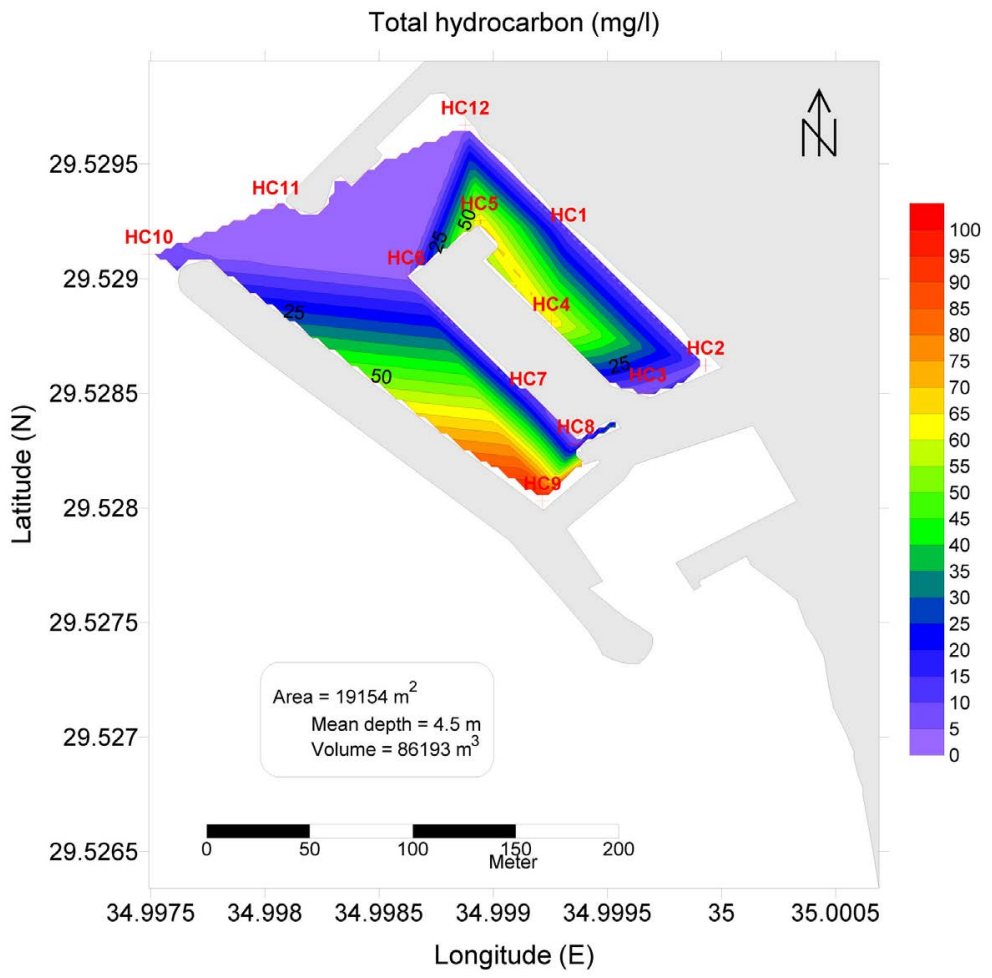

Figure 9. Total hydrocarbon concentration $(\mathrm{mg} / \mathrm{l})$ at seawater surface during summer at the sites (HC1 - HC12) in RYC's marina.

concentrations ranged between 185.6 - $591.8 \mathrm{ppb}$ with mean value of $351.3 \mathrm{ppb}$ compared to $43.1 \mathrm{ppb}$ at the control site [29]. This implies that the concentration of total hydrocarbon in RYC's marina is significantly lower than [29] study.

\subsection{Current Measurements}

The current speed vectors in and outside the RYC's marina at surface $(1 \mathrm{~m})$ revealed that seawater moved outward from the marina into the open sea. Besides, seawater at the bottom $(4 \mathrm{~m})$ moved inward the marine from open sea. The difference in the direction of movement at the surface and bottom created exchange system between the marina and open sea. On the other hand, the water movement inside the marina revealed a slight difference between surface and bottom, with weak and non-clear trend. The boundary of the marina controlled the direction of the current inside, which played a good role for enhancing the water exchange with open sea (Figure 10). The large values of standard deviation of current direction (Table 1) are due to multi-external driven forces and boundary of the marina that deviate these values within relatively large values. The average of current speed at the gate (sites c11 and c15) of the marina was $5.33 \pm 2.63 \mathrm{~cm} / \mathrm{s}$. The maximum and minimum average of current speed at surface was 8.92 and $0.64 \mathrm{~cm} / \mathrm{s}$ at site $\mathrm{c} 14$ (outside the marina) and c4 (inside the marina), respectively. At the bottom, the maximum and minimum average of current speed was 6.69 and $1.19 \mathrm{~cm} / \mathrm{s}$ at site $\mathrm{c} 12$ (outside the marina) and $c 9$ (inside the marina), respectively (Table 1).

The minimum flushing time of seawater inside the RYC's marina was 1.32 days. This flushing time is acceptable in term of securing a good environmental conditions and avoiding stagnation of seawater in the marina.

The average of residence time in the Ayla lagoons in the northern Gulf of Aqaba during the period June 2012-May 2013 as $2.58 \pm 0.66$ days [22], was assumed to be better and more than a proper time needed for ensuring a complete flushing in the lagoons in order to secure high quality environment. 

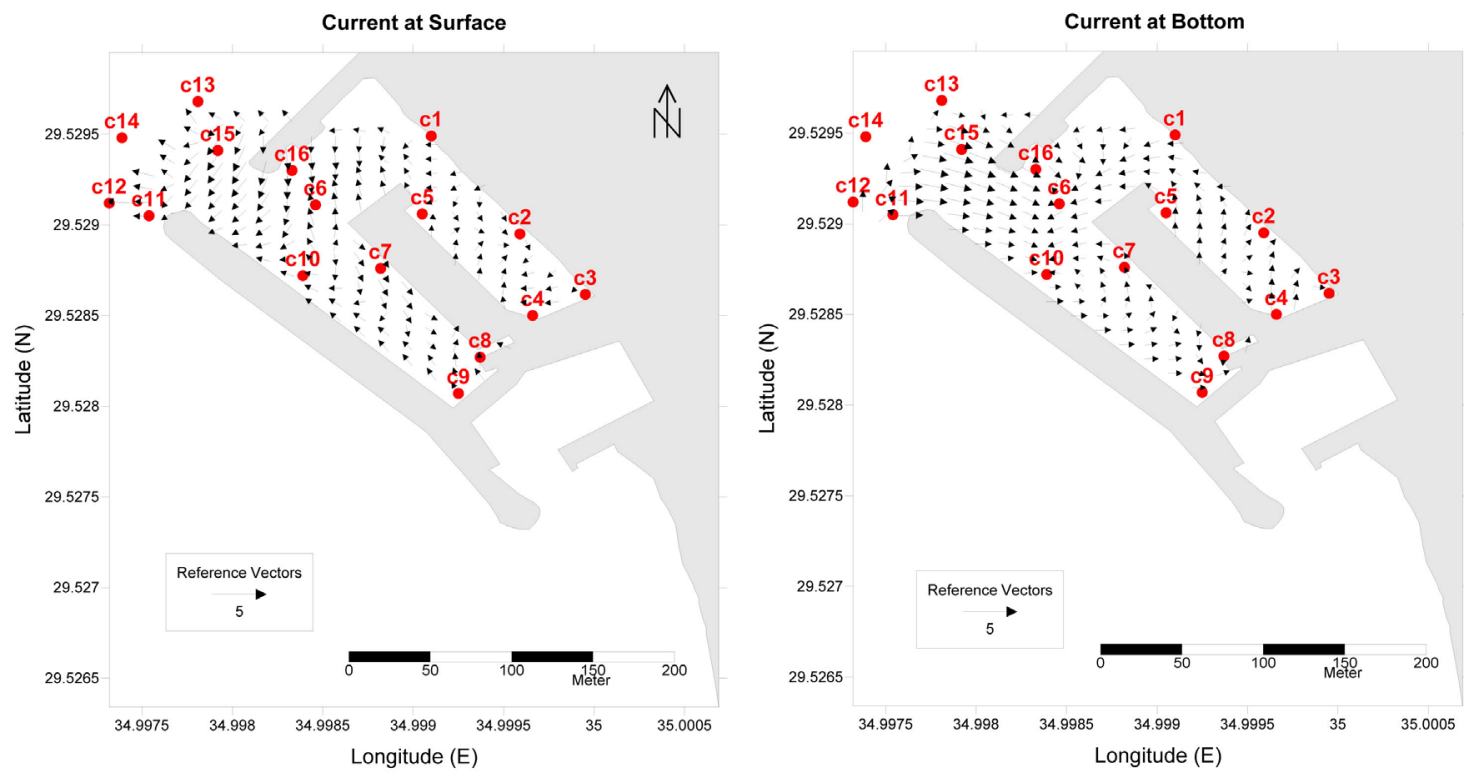

Figure 10. Current vectors $\left(\mathrm{cm} \cdot \mathrm{s}^{-1}\right)$ of seawater at surface and bottom in summer at the sites $(\mathrm{C} 1-\mathrm{C} 16)$ in RYC's marina.

Table 1. Statistical summary of seawater current speed and direction at surface and bottom in summer at the sites (C1 - C16) in RYC'smarina.

\begin{tabular}{ccccccccc}
\hline & \multicolumn{9}{c}{ SURFACE } \\
\cline { 2 - 8 } site & \multicolumn{2}{c}{ Speed $(\mathrm{cm} / \mathrm{s})$} & \multicolumn{2}{c}{ Direction $\left(^{\circ}\right)$} & \multicolumn{3}{c}{ Speed $(\mathrm{cm} / \mathrm{s})$} & \multicolumn{2}{c}{ Direction $\left(^{\circ}\right)$} \\
\cline { 2 - 8 } c1 & Average & STD $^{*}$ & Average & STD & Average & STD & Average & STD \\
\hline c2 & 1.76 & 0.83 & 215.72 & 49.24 & 1.79 & 0.66 & 203.09 & 57.51 \\
c3 & 1.56 & 0.85 & 53.27 & 42.00 & 1.45 & 0.77 & 41.89 & 42.31 \\
c4 & 1.37 & 0.66 & 282.49 & 51.47 & 1.53 & 0.84 & 345.69 & 46.04 \\
c5 & 0.64 & 0.85 & 59.40 & 53.01 & 2.06 & 0.78 & 21.56 & 56.89 \\
c6 & 2.48 & 1.59 & 183.59 & 34.19 & 1.94 & 0.99 & 138.06 & 43.10 \\
c7 & 4.62 & 2.34 & 48.55 & 61.07 & 4.79 & 2.67 & 12.78 & 63.60 \\
c8 & 2.94 & 1.27 & 147.63 & 52.42 & 1.91 & 1.22 & 176.70 & 45.29 \\
c9 & 2.92 & 2.19 & 112.75 & 25.18 & 2.63 & 2.05 & 158.90 & 18.89 \\
c10 & 1.55 & 0.55 & 137.54 & 41.18 & 1.19 & 0.50 & 134.12 & 45.60 \\
c11 & 2.50 & 1.63 & 306.14 & 52.62 & 2.38 & 1.48 & 270.49 & 58.44 \\
c12 & 3.95 & 2.99 & 28.32 & 51.08 & 4.56 & 1.69 & 26.05 & 51.29 \\
c13 & 6.26 & 3.10 & 100.40 & 47.26 & 6.69 & 3.12 & 253.11 & 46.58 \\
c14 & 3.56 & 1.40 & 145.68 & 52.60 & 2.19 & 1.51 & 232.38 & 46.70 \\
c15 & 8.92 & 3.90 & 330.70 & 44.83 & 7.47 & 2.68 & 329.69 & 47.69 \\
c16 & 6.71 & 2.27 & 140.17 & 59.40 & 5.61 & 2.30 & 138.06 & 58.63 \\
\hline
\end{tabular}

*STD: Standard deviation. 
In general, a study [6] revealed that the current in coastal waters in the open sea near the RYC below $12 \mathrm{~m}$ depth was weak $\left(3-6 \mathrm{~cm} \cdot \mathrm{s}^{-1}\right)$ and fluctuated from east-northeastward to west-southwestward (parallel to the shoreline), which may be related to the effect of bottom topography and/or current density due to differential cooling between eastern and western parts in the study area, and wind-induced upwelling and downwelling in the eastern and western side, respectively. The prevailing northerly winds and stratification conditions during summer were the main causes of the southward current at 6 and $12 \mathrm{~m}$ depths with average speed of 28 and $12 \mathrm{~cm} \cdot \mathrm{s}^{-1}$, respectively [6].

\subsection{Statistical Results}

A non-parametric test (Kruskal Wallis, $p<0.05$ ) was performed for comparison of temperature, salinity and density among sites. The non-parametric test was used since the raw data was non-normal distribution as well as also the comparison was between more than two groups. The comparison test of temperature, salinity and density (Table 2 and Table 3 ) revealed that there was no significant difference among all sites at surface and bottom. Mann-Whitney test (non-parametric comparison test) was used to compare the results of temperature, salinity and density between surface and bottom (Table 4). The results showed that no significant differences were detected for temperature and salinity between surface and bottom. On the other hand, the test revealed marginal significant differences for density between surface and bottom.

\subsection{Regression Results}

A correlation test among physical properties (temperature, salinity and density) and total hydrocarbon concentration was done in order to estimate the relationship between each parameter with another. The correlation test results manifested a very weak regression coefficient among all parameters, except for temperature vs. density $\left(\mathrm{R}^{2}=0.78 ; p=0.001\right)$ and salinity vs. density $\left(\mathrm{R}^{2}=0.28 ; p=0.002\right)$. This indicates that there was no correlation between total hydrocarbon and the physical parameters (Figure 11) of seawater in the RYC's marina. Therefore, the major factors of distribution of total hydrocarbon inside the marina are due to the current system and boats' movements as well as the location reference to the gate. On the other hand, a clear relationship was found between density vs. temperature and salinity (Figure 11).

\section{CONCLUSIONS}

The mean values of temperature, salinity and density inside the RYC's marina were $27.13^{\circ} \mathrm{C} \pm 0.03^{\circ} \mathrm{C}$, $40.51 \pm 0.02 \mathrm{psu}$ and $26.83 \pm 0.02 \mathrm{~kg} \cdot \mathrm{m}^{-3}$, respectively, which are comparable with open water. Besides, the statistical analysis revealed no significant difference of physical parameter among sites.

There was slightly high concentration of total hydrocarbon at some sites inside the marina, which may affect some aquatic lives. Therefore, it is important to give attention to regular cleaning and maintenance.

The distribution of total hydrocarbon inside the marina might be related to current system and boats' movements as well as the location reference to the gate.

The residence time of seawater in the marina in this period was 1.32 days. This time is very good for the exchange of water, which helps to mitigate any possible contamination.

\section{ACKNOWLEDGEMENTS}

The Authors would like to express their thankful for staff of the Marine Science Station/Aqaba and Mote Marine Laboratory/Sarasota-Florida for their help and support to accomplish this work. This work was written and analyzed while a Sabbatical Fellow from The University of Jordan/Aqaba Branch to Riyad Manasrah to be spent at the Mote Marine Laboratory in Florida USA. Fulbright scholarship was also awarded to Riyad Manasrah during this period. 
Table 2. Statistical summary and comparison test of seawater surface temperature, salinity and density in RYC's marina.

\begin{tabular}{|c|c|c|c|c|c|c|}
\hline \multirow{2}{*}{ Site } & \multicolumn{2}{|c|}{ Temperature $\left({ }^{\circ} \mathrm{C}\right)$} & \multicolumn{2}{|c|}{ Salinity (psu) } & \multicolumn{2}{|c|}{ Density $\left(\mathrm{kg} \cdot \mathrm{m}^{-3}\right)$} \\
\hline & Mean & STD & Mean & STD & Mean & STD \\
\hline $\mathrm{T} 1$ & 27.003 & 0.018 & 40.444 & 0.011 & 26.824 & 0.014 \\
\hline $\mathrm{T} 2$ & 27.071 & 0.007 & 40.455 & 0.004 & 26.810 & 0.003 \\
\hline $\mathrm{T} 3$ & 27.199 & 0.002 & 40.486 & 0.003 & 26.792 & 0.002 \\
\hline $\mathrm{T} 4$ & 27.109 & 0.009 & 40.440 & 0.003 & 26.786 & 0.004 \\
\hline $\mathrm{T} 5$ & 26.992 & 0.003 & 40.482 & 0.003 & 26.856 & 0.003 \\
\hline T6 & 26.994 & 0.021 & 40.516 & 0.004 & 26.881 & 0.010 \\
\hline $\mathrm{T} 7$ & 27.120 & 0.014 & 40.491 & 0.003 & 26.821 & 0.006 \\
\hline T 8 & 27.140 & 0.017 & 40.512 & 0.007 & 26.830 & 0.011 \\
\hline Т 9 & 27.354 & 0.012 & 40.514 & 0.006 & 26.762 & 0.007 \\
\hline T 10 & 27.109 & 0.003 & 40.508 & 0.003 & 26.837 & 0.003 \\
\hline $\mathrm{T} 11$ & 27.185 & 0.058 & 40.500 & 0.011 & 26.807 & 0.025 \\
\hline T 12 & 27.062 & 0.019 & 40.503 & 0.004 & 26.849 & 0.008 \\
\hline Т 13 & 27.361 & 0.015 & 40.346 & 0.017 & 26.633 & 0.018 \\
\hline Т 14 & 27.268 & 0.038 & 40.438 & 0.021 & 26.733 & 0.028 \\
\hline T 15 & 27.395 & 0.017 & 40.460 & 0.010 & 26.707 & 0.012 \\
\hline T 16 & 26.894 & 0.257 & 40.567 & 0.058 & 26.952 & 0.084 \\
\hline T 17 & 27.780 & 0.237 & 40.544 & 0.041 & 26.644 & 0.101 \\
\hline $\mathrm{T} 18$ & 27.229 & 0.057 & 40.497 & 0.018 & 26.790 & 0.032 \\
\hline \multirow[t]{3}{*}{ Т 19} & 27.264 & 0.046 & 40.513 & 0.017 & 26.791 & 0.023 \\
\hline & & \multicolumn{5}{|c|}{ Kruskal Wallis Test (Among sites at Surface) } \\
\hline & & \multicolumn{2}{|c|}{ Temperature $\left({ }^{\circ} \mathrm{C}\right)$} & Salinity (psu) & \multicolumn{2}{|c|}{ Density $\left(\mathrm{kg} / \mathrm{m}^{3}\right)$} \\
\hline \multicolumn{2}{|c|}{ Chi-Square } & \multicolumn{2}{|c|}{18.000} & 18.000 & \multicolumn{2}{|c|}{18.000} \\
\hline \multicolumn{2}{|c|}{ Degrees of freedom } & \multicolumn{2}{|c|}{18} & 18 & \multicolumn{2}{|c|}{18} \\
\hline \multicolumn{2}{|c|}{$p$-value } & \multicolumn{2}{|c|}{0.456} & 0.456 & \multicolumn{2}{|c|}{0.456} \\
\hline
\end{tabular}


Table 3. Statistical summary and comparison test of seawater bottom temperature, salinity and densityin RYC's marina.

\begin{tabular}{|c|c|c|c|c|c|c|}
\hline \multirow{2}{*}{ Site } & \multicolumn{2}{|c|}{ Temperature $\left({ }^{\circ} \mathrm{C}\right)$} & \multicolumn{2}{|c|}{ Salinity (psu) } & \multicolumn{2}{|c|}{ Density $\left(\mathrm{kg} \cdot \mathrm{m}^{-3}\right)$} \\
\hline & Mean & STD & Mean & STD & Mean & STD \\
\hline $\mathrm{T} 1$ & 26.931 & 0.021 & 40.486 & 0.009 & 26.879 & 0.013 \\
\hline $\mathrm{T} 2$ & 27.048 & 0.007 & 40.443 & 0.001 & 26.809 & 0.002 \\
\hline $\mathrm{T} 3$ & 27.225 & 0.008 & 40.485 & 0.005 & 26.783 & 0.006 \\
\hline $\mathrm{T} 4$ & 27.036 & 0.016 & 40.469 & 0.013 & 26.833 & 0.015 \\
\hline T5 & 26.975 & 0.001 & 40.500 & 0002 & 26.875 & 0.001 \\
\hline T6 & 26.961 & 0.005 & 40.518 & 0.001 & 26.893 & 0.002 \\
\hline $\mathrm{T} 7$ & 27.060 & 0.002 & 40.499 & 0.002 & 26.847 & 0.002 \\
\hline T 8 & 27.125 & 0.004 & 40.504 & 0.003 & 26.830 & 0.004 \\
\hline T 9 & 27.090 & 0.003 & 40.503 & 0.002 & 26.840 & 0.002 \\
\hline T 10 & 27.073 & 0.028 & 40.508 & 0.003 & 26.850 & 0.009 \\
\hline Т 11 & 26.544 & 0.003 & 40.522 & 0.001 & 27.032 & 0.001 \\
\hline Т 12 & 26.947 & 0.143 & 41.002 & 0.284 & 27.264 & 0.225 \\
\hline Т 13 & 27.293 & 0.022 & 40.416 & 0.021 & 26.708 & 0.023 \\
\hline Т 14 & 27.162 & 0.008 & 40.490 & 0.004 & 26.807 & 0.004 \\
\hline Т 15 & 27.390 & 0.009 & 40.503 & 0.017 & 26.742 & 0.015 \\
\hline Т 16 & 26.883 & 0.036 & 40.642 & 0.099 & 27.013 & 0.070 \\
\hline Т 17 & 27.220 & 0.003 & 40.527 & 0.020 & 26.816 & 0.017 \\
\hline Т 18 & 27.111 & 0.012 & 40.572 & 0.030 & 26.885 & 0.019 \\
\hline \multirow[t]{3}{*}{ Т 19} & 27.169 & 0.011 & 40.511 & 0.006 & 26.820 & 0.008 \\
\hline & & \multicolumn{5}{|c|}{ Kruskal Wallis Test (Among sites at Bottom) } \\
\hline & & \multicolumn{2}{|c|}{ Temperature $\left({ }^{\circ} \mathrm{C}\right)$} & Salinity (psu) & \multicolumn{2}{|c|}{ Density $\left(\mathrm{kg} / \mathrm{m}^{3}\right)$} \\
\hline \multicolumn{2}{|c|}{ Chi-Square } & \multicolumn{2}{|c|}{18} & 18 & \multicolumn{2}{|c|}{18} \\
\hline \multicolumn{2}{|c|}{ Degrees of freedom } & \multicolumn{2}{|c|}{18} & 18 & \multicolumn{2}{|c|}{18} \\
\hline \multicolumn{2}{|c|}{$p$-value } & \multicolumn{2}{|c|}{0.456} & 0.456 & \multicolumn{2}{|c|}{0.456} \\
\hline
\end{tabular}



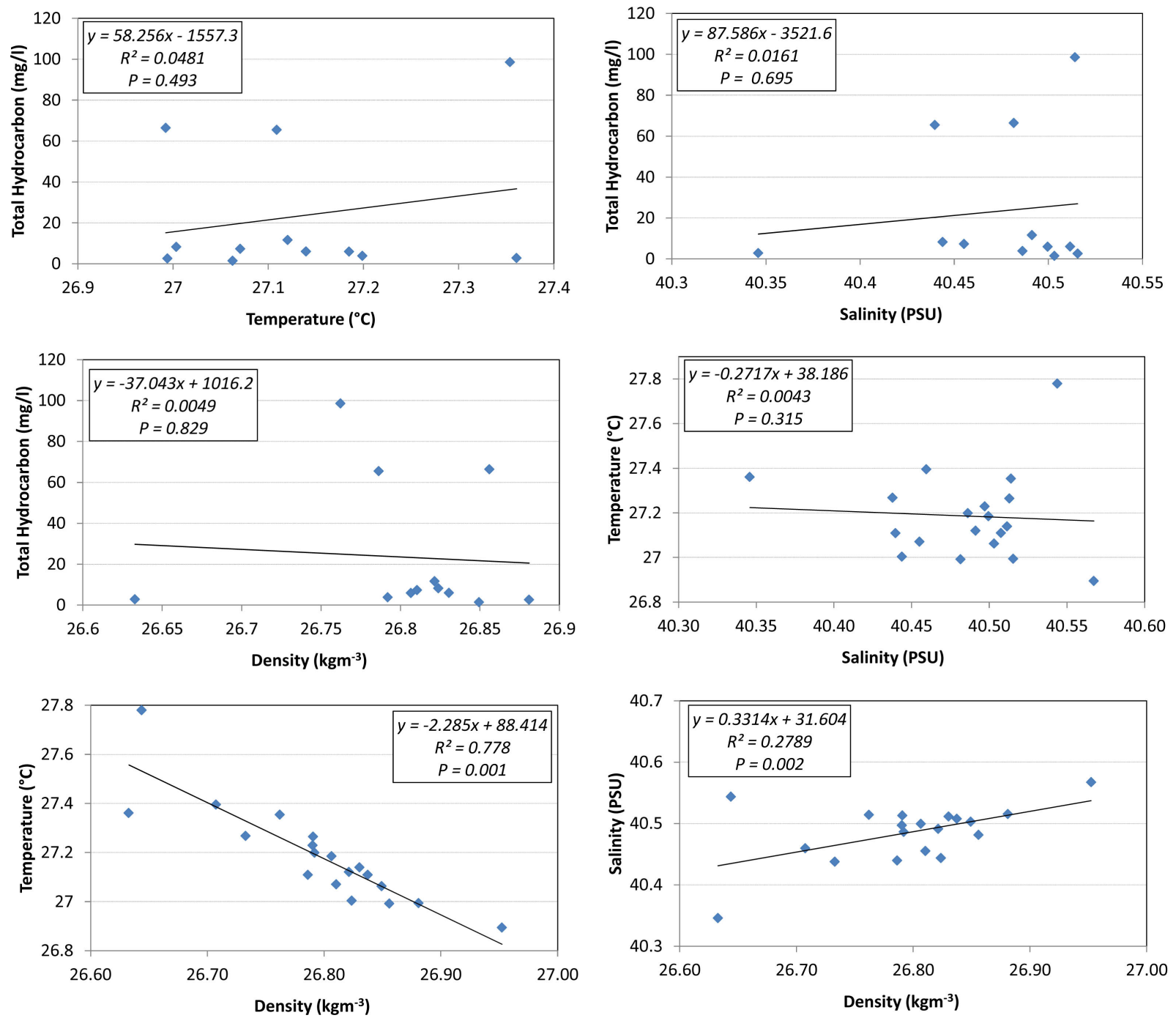

Figure 11. Relationship among the average seawater temperature $\left({ }^{\circ} \mathrm{C}\right)$, salinity $(\mathrm{psu})$, density $\left(\mathrm{kg} \cdot \mathrm{m}^{-3}\right)$ and total hydrocarbon concentration (mg/l) in RYC's marina.

Table 4. Comparison test of seawater temperature, salinity and density between surface and bottom in RYC's marina.

Mann-Whitney test (Surface vs. Bottom)

Temperature $\left({ }^{\circ} \mathrm{C}\right) \quad$ Salinity $(\mathrm{psu})$

Density $\left(\mathrm{kg} \cdot \mathrm{m}^{-3}\right)$

$p$-Value

0.085

0.234

0.032

\section{CONFLICTS OF INTEREST}

The authors declare no conflicts of interest regarding the publication of this paper.

\section{REFERENCES}

1. UNDP/ASEZA (2015) State of the Coastal Environment. Report for Aqaba, Gulf of Aqaba, Red Sea, ASEZA, Aqaba. 
2. Manasrah, R., Rasheed, M. and Badran, M. (2006) Relationship between Water Temperature, Nutrients and Dissolved Oxygen in the Northern Gulf of Aqaba, Red Sea. Oceanologia, 48, 237-253.

3. Fouda, M. and Gerges, M. (1994) Implications of Climate Change in the Red Sea and Gulf of Aden Region: An Overview. UNEP Regional Seas Reports and Studies, No. 156, UNEP, 58.

4. Manasrah, R. and Badran, M. (2008) Inter-Annual Seasonal Variations in the Seawater Thermohaline Structure in the Northern Gulf of Aqaba. Dirasat, Pur Sciences, 35, 123-135.

5. Al-Rousan, S., Rasheed, M., Khalaf, M.A. and Badran, M. (2005) Bottom Habitat and Biological Characteristics of the Jordanian Northern Gulf of Aqaba. Chemistry \& Ecology, 21, 227-239. https://doi.org/10.1080/02757540500211277

6. Manasrah, R., Zibdah, M., Al-Ougaily, F., Yusuf, N. and Al-Najjar, T. (2007) Seasonal Changes of Water Properties and Current in the Northernmost Gulf of Aqaba, Red Sea. Ocean Science Journal, 42, 103-116. https://doi.org/10.1007/BF03020878

7. Silberberg, M. (2004) Chemistry: The Molecular Nature of Matter and Change. 7th Edition, McGraw-Hill Education, New York, 1232.

8. Clayden, J.P., Greeves, N., Warren, S. and Wothers, P.D. (2001) Organic Chemistry. 53 Chapters, Oxford University Press, Oxford, 1508.

9. McMurry, J. (2000) Organic Chemistry. 5th Edition, Thomson Learning, Brooks/Cole, 75-81.

10. Kurylenko, V. and Izosimova, O. (2016) Study of the Impact of Petroleum Hydrocarbons on Sea Organisms. Journal of Ecological Engineering, 17, 26-29. https://doi.org/10.12911/22998993/61186

11. Brenner, S., Rosentroub, Z. and Bishop, Y. (1988) Current Measurements in the Gulf of Elat. Report H3/88.

12. Brenner, S., Rosentroub, Z. and Bishop, Y. (1989) Current Measurements in the Gulf of Elat 1988/89. Report $\mathrm{H} 8 / 89$.

13. Brenner, S., Rosentroub, Z. and Bishop, Y. (1991) Current Measurements in the Gulf of Elat 1990/91. Report H12/91.

14. Niemann, H., Claudio, R., Jonkers, H. and Badran, M. (2004) Red Sea Gravity Current Cascade Near-Reef Phytoplankton to the Twilight Zone. Marine Ecology Progress Series, 269, 91-99.

https://doi.org/10.3354/meps269091

15. Monismith, S.G. and Genin, A. (2004) Tides and Sea Level in the Gulf of Aqaba (Eilat). Journal of Geophysical Research, 109, C04015. https://doi.org/10.1029/2003JC002069

16. Manasrah, R., Badran, M., Lass, H.U. and Fennel, W. (2004) Circulation and Winter Deep-Water Formation in the Northern Red Sea. Oceanologia, 46, 5-23.

17. Berman, T., Paldor, N. and Brenner, S. (2000) Simulation of Wind Driven Circulation in the Gulf of (Aqaba). Journal of Marine Systems, 26, 349-365. https://doi.org/10.1016/S0924-7963(00)00045-2

18. Price, J.F., Weller, R.A. and Schudlich, R.R. (1987) Wind-Driven Ocean Currents and Ekman Transport. Science, 238, 1534-1538. https://doi.org/10.1126/science.238.4833.1534

19. Krauss, W. (1993) Ekman Drift in Homogeneous Water. Journal of Geophysical Research, 98, 20187-20210. https://doi.org/10.1029/93JC01898

20. Wikipedia (2013). https://en.wikipedia.org/wiki/Marina

21. Paldor, N. and Anati, D. (1979) Seasonal Variation of Temperature and Salinity in the Gulf of Aqaba. Deep-Sea Research, 26, 661-672. https://doi.org/10.1016/0198-0149(79)90039-6

22. Manasrah, R. (2015) Physical Properties and Exchange System of Seawater in Ayla Lagoons in the Northern Gulf of Aqaba, Red Sea. Fresenius Environmental Bulletin, 24, 1232-1249. 
23. Rasheed, M., Manasrah, R., Al-Trabeen, K. and Dixon, L.K. (2018) Impact of Artificial Lagoons on Seawater Quality: Evidence from 7 Years of Physicochemical Seawater Monitoring. Environmental Monitoring and Assessment, 190, 244. https://doi.org/10.1007/s10661-018-6620-8

24. Manasrah, R.S. (2002) The General Circulation and Water Mass Characteristics in the Gulf of Aqaba and Northern Red Sea. Meereswissenschaftliche Berichte (Marine Science Report), 50, 1-120.

25. Rasheed, M.Y. (1998) Assessment of Trace Nutrient and Chlorophyll a Concentration Gradient within a Coral Reef of the Gulf of Aqaba, Red Sea. M.S. Thesis, Yarmook University, Irbid.

26. Manasrah, R. (1998) Circulation of the Jordanian Waters of the Gulf of Aqaba, Red Sea. M.S. Thesis, Yarmouk University, Irbid.

27. Al-Sokhny, K.J. (2001) Biogeochemical Cycles of Nutrients and Chlorophyll a in Relation to Coastal Current in Jordanian Water of the Gulf of Aqaba, Red Sea. M.S. Thesis, Yarmook University, Irbid.

28. Al-Najjar, T. (2000) The Seasonal Dynamics and Grazing Control of Phyto- and Mesozooplankton in the Northern Gulf of Aqaba. Ph.D. Thesis, Bremen University, Bremen.

29. NPA (2003) National Program of Action (NPA) for the Protection of the Marine Environment from Land-Based Activities within the Red Sea Area in Egypt: Review on Pollution on Suez Canal, Hurghada, and Sharm El-Sheikh Areas. Marine Science Department, Suez Canal University, Ismailia. 